\title{
Drawing as memory and survival; painting and its relationship with history
}

Quote: GERALDO, Sheila Cabo; Carlos, ZíLIO. Drawing as memory and survival; painting and its relationship with history. Porto Arte: Revista de Artes Visuais. Porto Alegre: PPGAV-UFRGS, v. 22, n. 37, p.203-211, jul.-dez. 2017. ISSN 01037269 | e-ISSN 2179-8001. DOI: http://dx.doi.org/10.22456/2179-8001.80128

Translated by Roberto Cataldo Costa

Abstract: In an interview with Sheila Cabo Geraldo, visual artist Carlos Zílio recalls aspects of a trajectory that turned him into a reference in the field of art in Brazil since the second half of the 1960s. The conversation emphasizes, above all, the artist's political engagement, his imprisonment and the possible ways of resistance in that period; it also reviews the interaction with his generational peers (Gerchman, Vergara, Dias) with Iberê Camargo and French art historian Hubert Damisch. Finally, it discusses his perception about painting itself and his notion of an encounter with a "ground zero" of painting in the 1970 s, projecting its chances of permanence in contemporary times.

Keywords: Interview. Carlos Zílio. Art and politics. New Brazilian Objectivity. Painting.

Carlos Zílio (Rio de Janeiro, 1944) is a reference in the debate about the relationship between art and politics in Brazil - for both his work and his political activism. In his 20 s, he created the now canonical aluminum lunch tin with an inert human mask inside, with the word LUTE (FIGHT) in red, printed over the mask's mouth. At the same time, a year before the edition of [Brazil's military government's repression decree] Al-5, he composed the series of - static, indifferent - faces that resign themselves to a SIM (YES). Still in 1967, he painted E os Passos Prosseguem (And the Steps Continue), as a reference to the then recent execution of Ernesto Che Guevara. In 1970, he was arrested and seriously injured, and he spent two and a half years between army hospitals and military facilities.

Zílio's name is also unavoidable when discussing contemporary painting in Brazil. A former student of artist Iberê Camargo, he devoted himself to an inspired research on the possibilities of painting, based on a pop culture universe to reach circular, gestural and plain forms of refined expressive synthesis.
In the following interview, conducted by professor and researcher Sheila Cabo Geraldo in April 2016, Zílio comments on what he calls "ground zero" in relations between art and politics - and in painting itself. In the conversation so far unpublished, he speaks of his motivations as an artist, revises his trajectory and points out the different influences that indicated routes to be explored from Rubens to Mondrian. He also recalls his interaction with Iberê Camargo, with painters and friends Jorginho Guinle and Rubens Gerchman, and his encounter with historian and art theorist Hubert Damisch, author of the famous Theory of /cloud/. "Painting", Zílio says, "is the specific support that allows the exercise of history".

\section{SHEILA CABO GERALDO:}

In an interview with Fernando Cocchiarale and Paulo Sergio Duarte, ${ }^{1}$ among others, you refer to the drawings from prison as forms of memory and testimonies of survival. In the same interview, if I'm not mistaken, you also say that painting was your way of reinventing yourself. It struck me that the drawings, the prison paintings and then the plates would have this character of testimonies of survival, of memory and reinvention. Could you please tell me about that?

\section{CARLOS ZÍLIO:}

I had been without working for a year. I was a political activist, then I went underground. Let's say I stopped working in mid-1968 and was arrested in March 1970. I was still in the hospital when I asked for drawing material. I specifically asked for crayons and paper. I asked for books too. They didn't let me have the books but they gave me the drawing material. This initial request for material was a way to pass time, to keep my mind busy. As soon as I got the sketchpad and crayons, I began to do something like a narrative of what I was living. The drawings immediately became self-referential with that experience. It had been a tough experience and perhaps the drawings were necessary to be able to live with that trauma - of prison and especially the wound - a kind of catharsis.

1. ZíLIO, Carlos. "Entrevista: Fernando Cocchiarale. Paulo Sérgio Duarte. Vanda Mangia Klabin and Maria Del Carmen Zílio". In: . Arte e política. 1966-1976. 
And it continued as some sort of diary. This diary had to do with immediately past experiences and experiences of life in prison. So the drawings were a mixture of everyday narrative and a little remembrance of the circumstances that had led me to prison. They gradually took on that character - a diary. And they were also a way to use time in a productive way because... what can you do in a prison? I was in prison under several circumstances, in several places, sometimes with more people and sometimes fewer people. Our activity was very disciplined, like waking up, exercising, that sort of thing, like those prisons in war movies. It was a way not to fall into despair. Exercising, cleaning, classes - we would teach each other - reading, moments of silence. So the drawings were also a way to keep busy, but they were not just a hobby. I knew I was documenting something. I thought they were very poor, given the tools I had - basically paper and pilot - it was all a kind of rough draft of something that I would rework later.

\section{SCG:}

Did you think that? That they were drafts and you'd rework them later?

\section{CZ:}

I did. But then, when I got out of prison I saw what it was: experience. Even if I was alone - I spent time alone, spent about three or four months alone - I worked all the time.

\section{SCG:}

Did you used to write?

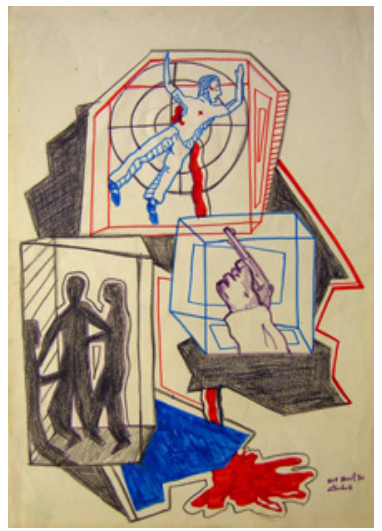

Figure 1. Carlos Zílio. HCE. Study No. 6, April 1970. Colored pencils on paper. Photo: Carlos Zílio.

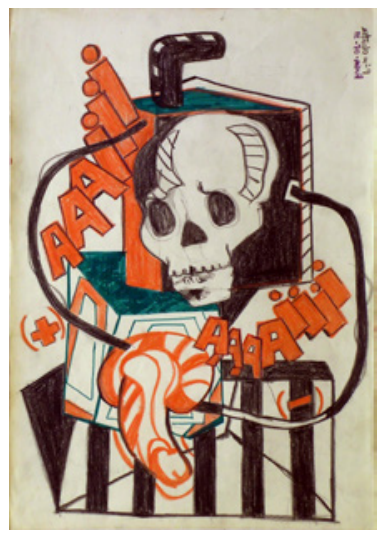

Figure 2. Carlos Zílio. Study No. 9, PE, April 1970. Colored pencils on paper. Photo: Carlos Zílio.

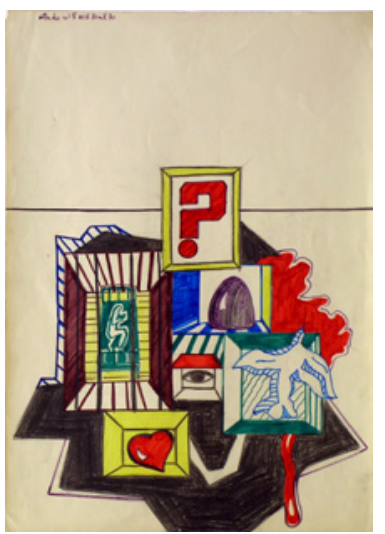

Figure 3. Carlos Zílio. Study No. 8, HCE, April 1970. Colored pencils on paper. Photo: Carlos Zílio.

CZ:

No, I didn't. I studied. The other day I found a notebook I kept. I started to study linguistics, Jakobson, that sort of thing. It was a way to keep busy, a way to focus on something. Total objectivity. My problem was that I had no real idea about how long I would be in prison.

SCG:

Had you not been to trial yet?

\section{CZ:}

No. according to the charges against me, I could get either two years or twelve years. Those were military procedures, so there was some indefinition. Things were defined within the 
legal precariousness of that time. They were military justice procedures, which meant precariousness within the general precariousness of justice - in the sense that legal norms were much more subjective. The judges were military. So it took me a while to have an idea about the time I was going to stay there. When they saw that I was going to get about two years I had already been in prison for two years. So I stayed for four more months or so and I got out. The trial happened later, when I was already out. But that's it: drawing was some kind of activity that made me resume my bond with art. It's curious because in the six or eight first drawings of those thirty-six you might see that l'm still coming back, relearning.

\section{SCG:}

Paulo Sergio relates these drawings with New Objectivity. Do you think that's right?

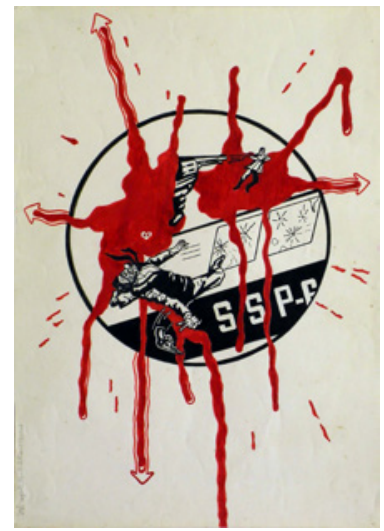

Figure 4. Carlos Zílio. Zé, August 1970. Color pen on paper. Photo: Carlos Zílio.

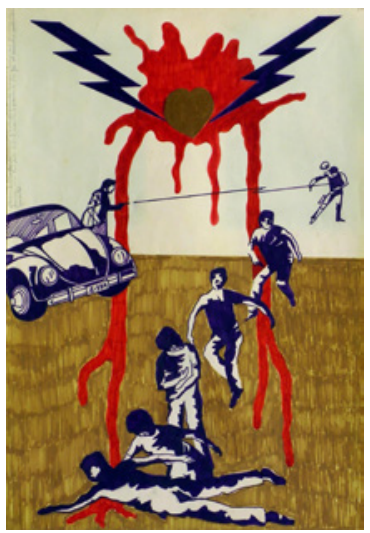

Figure 5. Carlos Zílio. The fall. December 1970. Color pen on paper. Photo: Carlos Zílio.

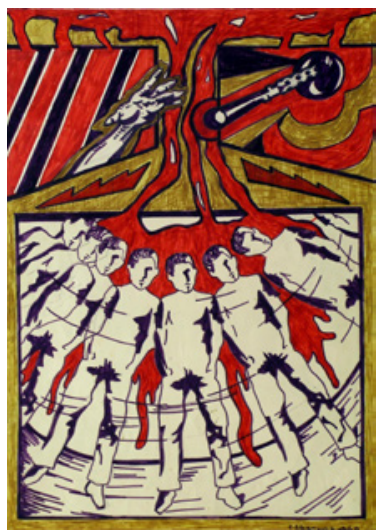

Figure 5. Carlos Zílio. Fixation. 1970. Color pen on paper. Photo: Carlos Zílio.

CZ:

Yes, there was some relation, but the works I did in the four exhibitions - Opinion 66, Salão de Brasília, Bienal de São Paulo, 67, and in Nova Objetividade - were objects. Some were lost. When I started drawing again, that was my reference, but now they were drawings. I resume, say, the language, but with other characteristics it was more narrative, more biographical, something that didn't exist in the previous period.

SCG:

In the interview I quoted, you also refer to the importance of the New Argentine Figuration for you. Do you think that the drawings' narrative might be referenced in the New Figuration?

CZ:

Yes, I believe there was some influence by the New Argentine Figuration. I don't know about everyone in my generation here in Rio, but [Rubens] Gerchman used to say that. Gerchman was a friend of Luis Felipe Noé's, and when I spoke to Noé, he said that Gerchman had told him that. In my specific case, the exhibition they did at MAM, which was a large show, with large works, I mean large for that time, since the scale was that of the MAM/ RJ block - the main building was still a skeleton of concrete, a structure. The exhibition was very important because it was the first art expression I saw that escaped the elements of pictorial tradition. It was what we called anti-art at the time, it resumed some figurative languages in other ways, it had this assemblage 
thing, something more related to life. It was collage under another figuration, with a type of material that they used, more industrial.

\section{SCG:}

More Pop?

\section{CZ:}

It was Pop, but it was more expressionist and somewhat neo-Dada. I saw it bit like that. And this caused a certain impact for someone was a student of Iberê's and considering that informalism was predominant. The argument between geometry and Informalism was already over, and in the early 1960s Informalism became a predominant language. We can see that in São Paulo Biennial awards to informal artists at that time.

\section{SCG:}

Was there political discussion?

\section{CZ:}

There was a political thing, there was this thing with life. With life and with materiality of life. Because they'd take things and glue them; it was very direct.

\section{SCG:}

Besides Noé, who was in that exhibition?

\section{CZ:}

It was Noé, De la Vega, Macció, they were four, I forget one. ${ }^{2}$

\section{SCG:}

Paulo Sergio also speaks about color in the prison drawings establishing a relationship with Russian constructivists, saying that the Russians used only black and red because of lack of material, but that in your case there was ideology.

\section{CZ:}

That palette things, right? That was the thing of the New Objectivity. We had that. We had very little in common, but let's

2. The Argentinian group worked between 1961 and 1965 and included Luis Felipe Noé, Ernesto Deira, Romulo Macció and Jorge de la Vega. look at five artists who characterized that production. Antonio Dias, [Rubens] Gerchman, [Carlos] Vergara and even Roberto Magalhães, who was not so involved anymore, and [Pedro] Escosteguy. Some formal elements undergo an order that is more related to mass language and iconography, hence those plain images.

\section{SCG:}

Black and red have more to do with graphic patterns, the press, communication.

\section{CZ:}

In prison, all I had was memory; I no longer had any influence by the present, so what I did was to retrieve those past instruments and adapt them to that new specific narrative of mine. It was less political in the sense of my works on politics and alienation. It was about the experience I was living. But that language was typical of advertising. The solid color, the possibility of communication and reproducibility, which were the concerns we had. I think these were the two common pillars: communication and reproducibility. Anyway, I think all of us exercised that but nobody actually ever did anything in terms of high numbers, but there was potential for that. When you add a third element, which is politics, these two things might refer to Russian constructivists, but in our case the most immediate reference was a pop feeling, not exactly Pop Art, of which we knew very little.

\section{SCG:}

Pop in the sense of mass culture?

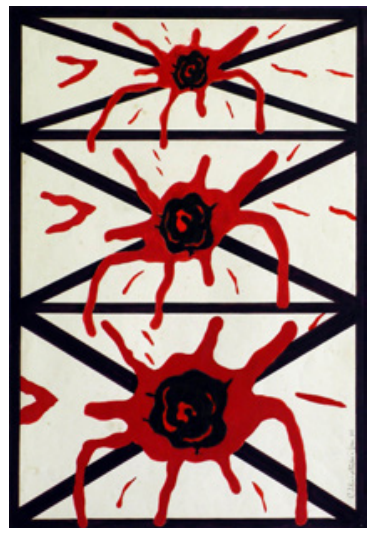

Figure 7. Carlos Zílio. The Near Departure, 1971. Color pen on paper. Photo: Carlos Zílio. 


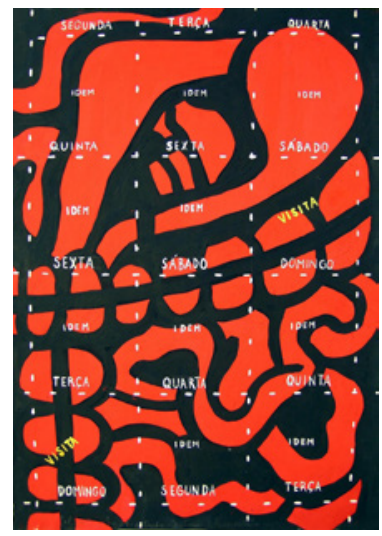

Figure 8. Carlos Zílio. Dilacerating routine, 1971. Gouache on paper. Photo: Carlos Zílio.

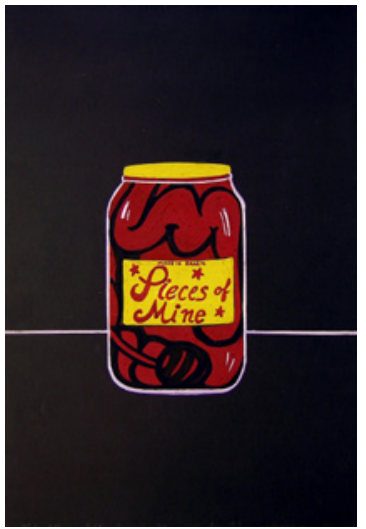

Figure 9. Carlos Zílio. Pieces of mine, 1971. Gouache on paper. Photo: Carlos Zílio.

CZ:

Pop in the sense of a world that makes everything into mass, of that visuality.

SCG:

I'm curious: when you studied with Iberê [Camargo], what did you paint?

\section{CZ:}

Iberê's class... If you pick up ten students of Iberê's and each of them might say something different. But I can say that there was always a model, whether it was a living model or a still life. He wouldn't go there and say "create". Usually the living model was used for drawing. In that case they were exercises that he cultivated and sought to induce, such as exercising the line, only the line attached to the model and consequently to a figurative narrative where he proposed a reinterpretation of the model, already thinking about the surface of the paper. Broadly speaking, l'd say that he induced us, although he was not an artist dear to Iberê, to something inspired by Matisse or Picasso's line drawing. And in still life, it was a post-Cubist lesson. I guess it was ultimately what André Lothe conveyed to him. Iberê was Lothe's pupil, and that's what Lothe was, this didactic codification of Cubism. I think that's what Iberê passed on to us. That's how the lessons were, twice a week. In the meantime, we'd paint by ourselves, and this work was later analyzed by Iberê. Now, besides that, the environment was very much based on the contact with the master, that contact with the figure of the artist, what the artist was, how he behaved, how he related to the world, what the artist's subjectivity was - all that was very important as an example of an artist's ethic. It was all very absorbing at the time.

\section{SCG:}

In the late 1970s, during the period you were in France from 1976 to 1980 , you also resumed painting. And you talk a lot about your contact with Cézanne and Rubens. I'm curious about Rubens. Why Rubens?

\section{CZ:}

The question is not why Rubens. Rubens is one of Cezanne's references. I got into that as tradition, and one of the ways I accessed that tradition was through Cézanne. Cézanne speaks of Rubens, but also speaks of Poussin - artists from the same period but with different vocations. That's not the problem. The problem is the relationship with history. I'll try to be synthetic. You have these prison drawings and the paintings I made when I got out of prison, which at first were some sort of continuity of the prison drawings and then they acquired a more conceptual character. When I made these more conceptual paintings, to me it was as if there was some thickness in the ground zero of painting. This was very clear for us. This modern avant-garde feeling was still very clear, and its limit was Malevitch. The first time I went to MoMA and I saw Malevitch and Mondrian of course artists I still admire, Mondrian specially - there was something fresh. You see this in the Oiticica of that 
time, considering the proportions. Oiticica in New York thinks only of Malevitch. He only thinks: “No, deep down it's Malevitch". That was vital. And for me it was the zero of the painting. Painting had reached its zero. So those painting exercises I did in the 1970s, between 1973 and 75, were a possibility that there was still some thickness in that zero, some tension, anything there that could hold potential, an existence that could directly address this feeling of a blank slate, of zero. So that's what I worked on, and when I started making objects, an installation at MAM in 76 and then at the Paris Biennial, it was a departure from painting because I felt like I was searching in a place already exhausted. Zero was a radical thing.

\section{SCG:}

I remember that in the 80 s you made a series of paintings with a narrative that is very close to discussions in Brazilian painting. And that period is quite different from finding a blank slate or painting's zero. It was from that painting that I came to think of painting as permanence, even having identified that zero in the 1970 s.

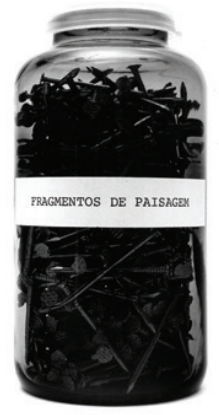

Figure 10. Carlos Zílio. Landscape Fragments, 1974. Glass and nails. Photo: Carlos Zílio.

\section{CZ:}

This was a result of that Parisian time. I arrived in Paris with this Brazilian baggage, but with many doubts, many questions. Those questions existed because I thought I did political art and they were inseparable things. There was a link between art and politics, which came from my view of history and art history. My story was a story of dialectical ruptures and overcoming, which led me to a vision of progress, that vision of overcoming and improvement. At least for my vulgar Marxism and my militant ideology it worked that way. While my work sought to develop this when I got out of prison, I had a very strong feeling of defeat. It was a whole project, which my view about history justified, that had been defeated. To get a clearer view of this: I remember I was in the army hospital and at the room where I stayed there were always one or two guards with me, because it was a prison-hospital. I don't know why they were inside the room, because they could stay outside. They worked in shifts. Coincidentally, one of them was there two or three times. And I managed to establish a conversation with the guy and I was feeling bad, recovering, very bad, but I established a bond with him and around the third time he was on guard I told him: look, here's the thing: get out of that job because within six months or a year, all this will end and you will be in the middle of it. If I were you l'd find another place.

\section{SCG:}

You really believed it, didn't you?

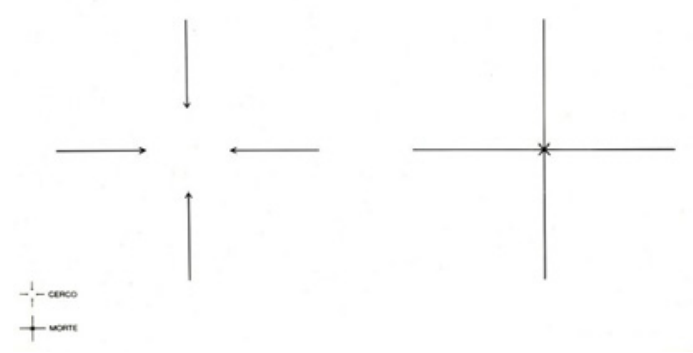

Figure 11. Carlos Zílio. Siege-Death, 1974. Acrylic on canvas. Photo: Carlos Zílio.

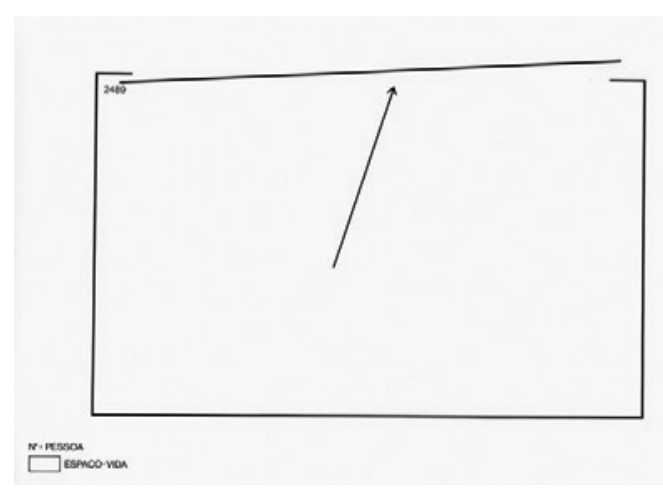

Figure 12. Carlos Zílio. The Instant of Liberation, 1974. Acrylic on canvas. Photo: Carlos Zílio. 


\section{CZ:}

I told him just like that. This view of an utopia, of something to be built, was concrete. It was not subjectivity. It was what allowed us to do all those crazy things without anything other than ideology. So when I come out of jail, I come with the view that all that had been defeated. But it could be a defeat of a political line and not of political foundations. But the $70 \mathrm{~s}$, from the $60 \mathrm{~s}$ to the $70 \mathrm{~s}$ have some interesting things. You have one thing very present, which was the Vietnam War. The war was very invasive, either because of the space it occupied in the press or because it was the first and last war broadcast live. Americans learned from that. Then, in the Iraqi War, they did the coverage of the occupation Star Wars style. That thing of the Vietnam War, of the American mother watching television and suddenly seeing, by chance, her son being shot - that's over. But it was a very present war. A war that involved the whole world politically because it was there on the border of the Cold War. And it had a very heroic dimension. A people from Southeast Asia, a very poor country, that confronted the strongest power in history, and won. The Cuban Revolution had already taken place, which had effects in Latin American countries, and then the War in Vietnam. So, this helped strengthening my ideology in terms of utopia. But the 1970s, after all that, went on the opposite direction. Vietnam was liberated and went to war with China. Because it was not a problem of broader political spectrum, of socialism versus capitalism. It was a localized, cultural geopolitical problem. Vietnam had historical issues with China. Soon after that there was Vietnam's War with Cambodia. Certain situations were unthinkable ten years earlier. In addition, Cuba was already beginning to be heavily criticized for its undemocratic aspects. So my sense of defeat, which was still the defeat of a political line based on "Foquism", had now become broader. It was serious questioning of the socialist proposal, wondering what real socialism was, no longer in the university, in theory, but socialism in the world. What was happening? That thing shook me a lot. I'm saying this because art and politics were one thing.

Then I went to France. Well, in the sense of art and politics being one thing, before I went to France, there was already the problem of Brazilian art. What was that? What was Brazil, what was a politics for Brazil and what was a politics of art in Brazil? In France I developed my relationship woth history, on top of that fracture I feel of that project of history, of dialectical materialism, which no longer sustained itself in the face of the reality that socialism in practice was passing. That discomfort for me was the discomfort of that view of political development, of historical development. And what was the ground zero? It was that. It was the revolution. It becomes a blank slate and everything starts from scratch again, the revolution of ground zero, of Malevitch's zero square. What is it? Is it really zero? When I arrived in France, I still refused to enter the Louvre. Then you have an idea of what it was like. In 1974 I obtained a passport and left Brazil. I spent two months traveling. I didn't go to any museum that was not modern or contemporary. I even went to Cologne just to see a collection, which used to be the largest, say, "postmodern" collection that existed at the Ludwig Museum. Today it's just another museum, but it used to be one of the places with contemporary art, because MoMA went only until a certain point. In France I didn't even walk by the Louvre's door. But when I arrived in France (1976) I had all these doubts.

I remember an image of something I had lived during that trip in 1974 when I was in Florence. It was not in any museum; it was on the street. Near Florence's cathedral they had dug a hole for construction works. The workers soon stopped and surrounded it. I saw this for the first time. They had found several historical layers, everything was mapped up there, an archaeological site. Then when I arrived in France, archeology was forming little by little in my head. Ground zero was not ground zero. History is not linear. I got this other sense from my experience with art.

I arrived in France at a particularly fertile time because it coincided with the opening of the Beaubourg. Then there was this great Cézanne exhibition that I saw in the Grand Palais. So Cézanne was this, it was the hole next to the Florence Cathedral.

\section{SCG:}

That's when you got in touch with Jasper Johns, wasn't it? Which was also important.

CZ:

It was at the exhibition at the Beaubourg, in his retrospective. Because Jasper Johns has that layer thing, which has to do with Cézanne, which in turn contains Poussin. I guess that's what painting has given me. And [Hubert] Damisch's lessons at the same time. 


\section{SCG:}

That's what I wanted to know. Was Damisch crucial?

\section{CZ:}

He was crucial. I had the impression that you would sit in your chair, tighten your seatbelt, and then it was that intellectual vertigo of going through the history of art from side to side, back and forth. It was that internal articulation, which he used to do a lot, like Warburg. This thing of going back and forth, traveling through the work of an artist and then reaching the work of the other, always opening up new meanings. It's vertiginous. I've just visited him in February. There was an exhibition in his honor at the Beaubourg, where painting and architecture were exhibited... He was very important to me.

\section{SCG:}

And when you went back to Brazil, how was this dive in art history, which you were already doing; after all you wrote your thesis there, but in pictorial terms, with painting, really?

\section{CZ:}

Yes, I wrote it there. But in terms of painting, we'd have to take it easy. I'd have to show how this was changing. I defended my thesis and came back to Brazil. Damisch's cosmopolitanism was accompanied by immersion in Brazil, all the time. With this thesis stuff you don't leave home, you just write, and sometimes I had to go around the corner to buy the newspaper and remember I was in France. And when I came back, I brought that a lot with me, Brazil through a broader lens. Some issues were already in my concerns, like abstract Expressionists. I had already seen Monet's Nympheas. All the time I lived in France, the Orangerie was closed for restoration. Jorginho [Guinle] kept telling me that I had to see that Monet. I said: I can't see it, it's closed. It opened in my last month there. So when I came back I had some issues in mind.

In Brazil there were two artists that interested me most in productive terms: Volpi and Tarsila. Tarsila because - I don't know if anyone has written about it, I don't know literature on Volpi well - but I think there's Tarsila in Volpi. And I started working. It was these people who were diluted in the work to a certain extent. I can comment on that more specifically later. It was a lot more of internal motivation, but they were important, right? Certain works from the early 1980 s are longitudinal rectangles. Why? Because there is Monet in there. They have continuous bands. Why do they have continuous bands? All over. The colors are secondary and diluted because of Volpi. Didactically speaking, that's how it goes.

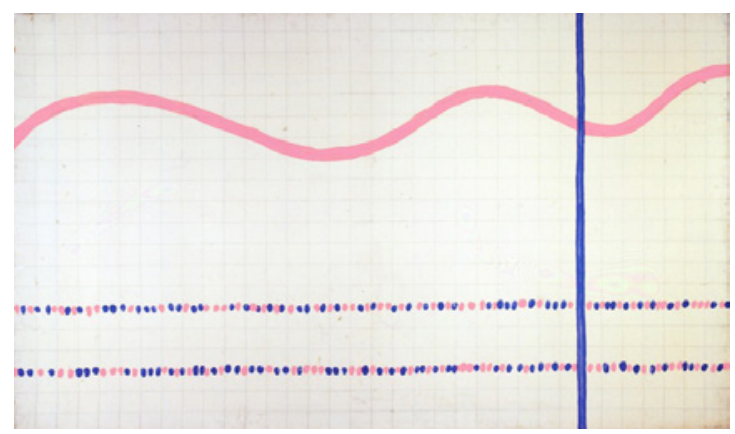

Figure 13. Carlos Zílio. Tico-Tico no Fubá, 1979. Acrylic on canvas. Photo: Carlos Zílio.

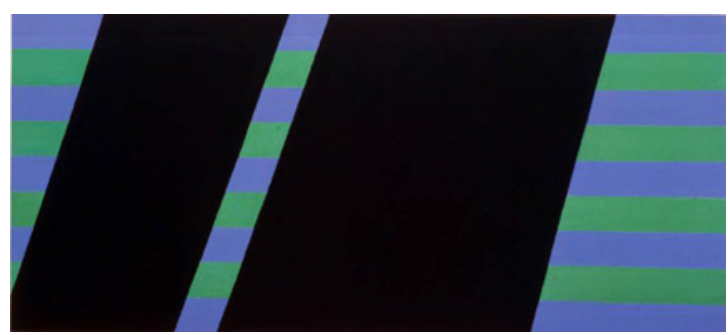

Figure 14. Carlos Zilio. Attempt to See the Balcony through the Window and the Gate, 1983. Acrylic on canvas. Photo: Carlos Zílio.

Nowadays art has become something else. It's different, it's somehow a consequence of what I have experienced. We were the iconoclasts. But it's alright. Art has taken on another dimension, other languages, other possibilities in a diverse world with many possibilities. When I resumed painting, I felt I was doing something that had no guarantee, no institutional or public assurance at that time. The ideology was that of the death of painting. That lasted ten years or so. Then painting reappeared forcefully and diversified. I think painting is the specific support that allows the exercise of history in this new field of art. That's what interests me. 
Carlos Zílio: lives in Rio de Janeiro. The most recent group exhibitions he has taken part in include Transmissions: Art in Europe and Latin America 1960-1980, MoMA, NY, Possibilities of the Object: Experiments in Modern Brazilian Art, The Fruitmarket Gallery, Edinburg, both in 2015, Uma história da Pinacoteca de São Paulo, Roger Wright Gallery, in 2016, and Modos de Ver o BRASIL, OCA, São Paulo, in 2017. His last solo exhibitions took place in 2016 at Raquel Arnaud Gallery, in São Paulo and MAM-RJ, and in 2017 at the Anita Schwartz Gallery, in Rio de Janeiro.

Sheila Cabo Geraldo: is an Art History researcher and professor at the Graduate Program in Arts of the State University of Rio de Janeiro (PPGArtes/UERJ). She organized the books Trânsito Entre Arte e Política (Quartet/Faper, 2012j); Narrativas e subjetividades, with Luis Cláudio da Costa (Quartet, 2012); Fronteiras: Arte, Imagem, História (Beco do Azougue, 2014). She currently develops research on memory politics and studies on colonialism and postcolonialism in Latin America.

(*)This text was submitted in November 2017. 